\title{
8
}
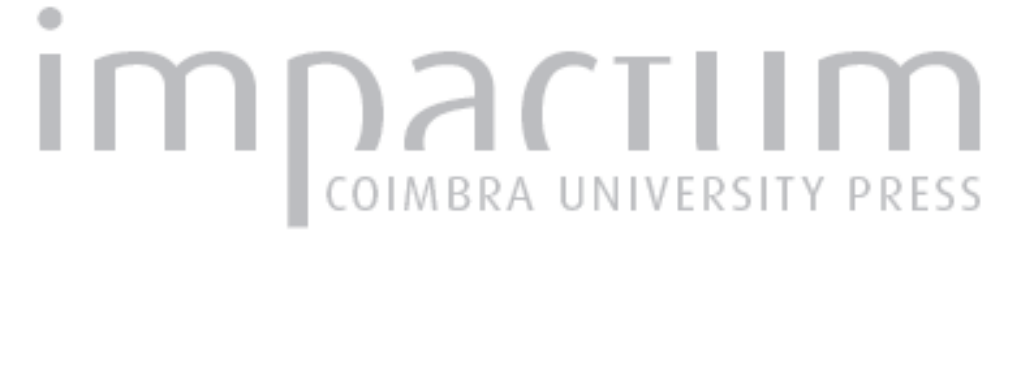

\section{A presença portuguesa no Rio da Prata (1678-1777): como foi vista e explicada por Luís Ferrand de Almeida}

Autor(es): $\quad$ Magalhães, Joaquim Romero Publicado por: Faculdade de Letras da Universidade de Coimbra, Instituto de História

URL

persistente:

DOI: $\quad$ DOI:http://dx.doi.org/10.14195/0870-4147_43_6

Accessed : $\quad$ 26-Apr-2023 11:27:50

A navegação consulta e descarregamento dos títulos inseridos nas Bibliotecas Digitais UC Digitalis, UC Pombalina e UC Impactum, pressupõem a aceitação plena e sem reservas dos Termos e Condições de Uso destas Bibliotecas Digitais, disponíveis em https://digitalis.uc.pt/pt-pt/termos.

Conforme exposto nos referidos Termos e Condições de Uso, o descarregamento de títulos de acesso restrito requer uma licença válida de autorização devendo o utilizador aceder ao(s) documento(s) a partir de um endereço de IP da instituição detentora da supramencionada licença.

Ao utilizador é apenas permitido o descarregamento para uso pessoal, pelo que o emprego do(s) título(s) descarregado(s) para outro fim, designadamente comercial, carece de autorização do respetivo autor ou editor da obra.

Na medida em que todas as obras da UC Digitalis se encontram protegidas pelo Código do Direito de Autor e Direitos Conexos e demais legislação aplicável, toda a cópia, parcial ou total, deste documento, nos casos em que é legalmente admitida, deverá conter ou fazer-se acompanhar por este aviso. 



\title{
A presença portuguesa no Rio da Prata (1678-1777): como foi vista e explicada por Luís Ferrand de Almeida
}

\author{
JoAQuim Romero MAGALHÃES \\ Professor Catedrático da Faculdade de Economia \\ Universidade de Coimbra \\ jromero@fe.uc.pt
}

Resumo:

Depois de focar o importante papel dos acidentes geográficos, mormente os rios, na definição de limites territoriais, o Autor debruça-se sobre um caso concreto, o da construção de uma fronteira entre as colónias portuguesa e brasileira da América do Sul, sobretudo no seu limite Sul, no Rio da Prata, nos séculos XVI, XVII e XVIII.

Palavras chave:

Fronteira; Diplomacia; Relações PortugalEspanha; Construção do Brasil.
Abstract:

After considering the important role of landforms, specially rivers, in the definition of territorial limits, Luís Ferrand de Almeida focuses on a specific case, the making of a frontier between the Brazilian and Portuguese colonies in South America, particularly in its southern boundary, in Río de la Plata, in the 16 th, 17th and 18th centuries.

Keywords:

Frontier; Diplomacy; Portuguese-Spanish relationships; Making of Brazil. 
O Tratado de Tordesilhas de 2 de Julho de 1494 - um dos tratados assinados pelo português D. João II com o casal castelhano-aragonês Isabel e Fernando marcou a expansão hispânica pelos mares e territórios do Atlântico, por terras que depois se ficariam a chamar América. Entre os reis peninsulares havia que determinar o que pertencia a um e aos outros impondo aos povos peninsulares o respeito por áreas que não se podiam definir no tempo das assinaturas. Porque se no século XV já se sabia medir a latitude com um relativo rigor, a longitude teria que aguardar pelos progressos técnicos e científicos do século XVIII - por observações astronómicas e pela invenção do cronómetro de precisão. Mas o que acontece é que os práticos e os governantes tinham mais ou menos uma noção aproximada dos limites: pela embocadura do Amazonas no Norte e pelo litoral de Cananeia na costa do Brasil ao Sul de Santos.

Nunca a demarcação de fronteiras é coisa fácil e uma área extensa dificilmente pode marcar a junção - ou separação - entre dois territórios. Ao longo dos séculos têm sido as guerras e as soluções diplomáticas com que se condicionam os conflitos internacionais a conduzir à desejável definição das fronteiras. Soluções por vezes trabalhosas. Há que escolher, e normalmente os responsáveis políticos optam pelas mais evidentes ou mais fáceis das linhas que se podem prestar a servir como divisórias. Assim os cursos de água e as serras. Todavia essas fronteiras são quase sempre impossíveis de conservar. A menos de serem largas extensões desocupadas. Porque é o deserto na ocupação humana o que separa, não o acidente geográfico em si mesmo. Os rios são sempre grandes vias de comunicação, embora muitas vezes escolhidos para servir de limites.

Logo no século XVI os portugueses tiveram a percepção de que a fronteira sul do Brasil ficava sem defesa ou com uma defesa precária pela delimitação fixada no Tratado quatrocentista. A realidade física e as condicionantes económicas depois impuseram-se. Castela e as suas Índias, ao descobrir-se a prata no Potosí por 1545-1546, escolheram o Oceano Pacífico e a rota de Callao ao Panamá para estabelecer o eixo da circulação do seu império. ${ }^{1}$ Portugal manteve-se buscando metais preciosos, sem os obter na sua parte no Brasil. E os colonos foram cultivando a cana sacarina, com o que se organizou uma colónia de base agrícola na fachada atlântica. Essa ausência de metais provocava confusão: por que não se descobriam ouro e prata em terras brasileiras, tão próximas aos

1 Earl J. Hamilton, Los tesoros americanos y la revolución de los precios en España, 1501 -1650, trad., Barcelona, Editorial Crítica, 2000, p. 26-27 e 30-35; Pierre Vilar, Oro y moneda en la Historia (1450-1920), 2 a ed., Barcelona, Ariel, 1972, p. 186-196; Alice Piffer Cannabrava, O comércio português no Rio da Prata (1580-1640), $2^{\text {a }}$ ed., Belo Horizonte - São Paulo, Ed. Itatiaia - Ed. da Universidade de São Paulo, 1984, p. 44-47. 
tesouros das Índias? Pergunta motivadora. Mais e mais portugueses penetram pelo interior do Continente escravizando os indígenas que podem e não esquecendo de buscar indícios de metais preciosos. Porque a limitação entre os espaços para a expansão de uma e outra coroa não era uma limitação muito respeitada. E poderia sê-lo em tais distâncias, com meios tão rudimentares e com tão pouca gente?

Por isso a questão da raia ficou quase esquecida por mais de um século. O território a repartir parecia não ter fim. Os súbditos da coroa de Castela continuam explorando as suas minas, os da coroa de Portugal cultivando os seus açúcares, transportando os seus escravos africanos, capturando e vendendo outros seus escravos mal-chamados índios. E por isso se internam nas selvas tropicais para os agarrar, prendê-los e depois impor-lhes trabalhos. O espaço era uma imensidade, e os problemas de fronteiras por isso não foram importantes nem necessários nos primórdios da colonização.

Os espaços castelhanos não se abriram aos portugueses, nem os espaços portugueses aos castelhanos. Porém, os portugueses actuaram como se essa fora a legalidade. Correndo os caminhos da América do Sul sem respeitarem a linha de Tordesilhas que não queriam saber por onde passava. Nem serem incomodados por não o saberem. Talvez ignorassem de todo que havia uma linha de separação. E aproveitavam para fazer contrabando com as comunidades próximas: a cidade da Santíssima Trindade e Porto de Santa Maria de Buenos Aires, recriada em 1580, tinha muitos portugueses entre os seus vizinhos. Boa parte deles interessada no comércio com o Brasil. Mas o soberano mantinha a cidade como "porto fechado" - o que pode dizer-se que era uma extravagância da política espanhola. ${ }^{2}$ Só depois de 1602 se abriram algumas possibilidades de legalização de permutas com o Brasil. ${ }^{3}$ Em 1618 inicia-se a importação de escravos africanos. O que só ocorrerá com intermitência. ${ }^{4}$ Enquanto o contrabando se organiza. Com conivência de mercadores com

2 C. H. Haring, Comercio y navegación entre España y las Indias en la época de los Habsburgos, trad., México, Fondo de Cultura Económica, 1939, p. 176-180.

3 Alice Piffer Cannabrava, O comércio português no Rio da Prata (1580-1640), p. 71-76; C. H. Haring, The Spanish Empire in América, New York, Oxford University Press, 1947, p. $96-97$;

4 Alice Piffer Cannabrava, O comércio português no Rio da Prata (1580-1640), p. 78; Guilhermino Cezar, O contrabando no Sul do Brasil, Caxias do Sul - Porto Alegre: UCS - EST, 1978, p. 11-17. 
autoridades locais. ${ }^{5}$ Pelas cidades entretanto fundadas com ligações ao Prata relacionam-se os interessados: Buenos Aires, Santa Fé, Córdoba, Mendoza, Tucumán, Asunción. ${ }^{6} \mathrm{O}$ que significa que, ainda que ilegal, se consideraria normal a prática do contrabando, sobretudo crescendo e ganhando posições quando o comércio era proibido, como não podia deixar de ser. Porque as minas de prata do Potosí necessitavam do comércio do Brasil muito em especial de escravos africanos. Do Brasil chegavam a Buenos Aires e ao Prata tecidos de algodão e mercadorias europeias além de alimentos (açúcar, arroz, farinha e ainda os famosos doces de marmelo de São Paulo). ${ }^{?}$

A mudança de consideração política e económica pelo que toca às fronteiras vai ocorrer com a Restauração de 1640. Com um golpe ocorrido em Lisboa, Portugal separava-se dos outros domínios dos Áustrias de Madrid na Península Hispânica. O que ia repercutir na América do Sul. Havia agora que bem delimitar as fronteiras - os territórios passavam a ser pertença de dois reis e não apenas de um. Mas aos Portugueses não lhes interessa regressar às delimitações do Tratado de Tordesilhas - mesmo se isso podia pôr em dúvida a soberania espanhola sobre as Filipinas (e a seu favor). ${ }^{8} \mathrm{O}$ que querem é desenhar linhas fronteiriças que não acarretem dificuldades de segurança. Por isso as invocadas fronteiras naturais parecem as mais adequadas: rios e montanhas, como sempre que se referem as fronteiras naturais. É o tempo em que na Europa a França de Richelieu procura também afiançar-se no Reno. Ora a coroa portuguesa sempre tinha considerado o Rio da Prata como português. Dali se conseguia retirar não pouca prata. E esse era o seu principal atractivo. Por ser ainda uma aproximação possível às minas do Potosí. Sem embargo de ilegal. Mas assim se

5 José Luís Romero, Breve historia de la Argentina, $2^{\mathrm{a}}$ reimp., Buenos Aires, Fondo de Cultura Económica, 2005, p. 30-31; M Emelina Martín Acosta, El dinero americano y la política del Império. Madrid, Colecciones Mapfre, 1992, p. 220.

6 Alice Piffer Cannabrava, O comércio português no Rio da Prata (1580-1640), p. 124-130; Stanley J. Stein e Barbara H. Stein, Plata, comercio y guerra. España y América en la formación de la Europa moderna, Barcelona, Crítica, 2002, p. 48-49; L. A. Moniz Bandeira, O expansionismo brasileiro e a formação dos Estados na Bacia do Prata. Da colonização à Guerra da Tríplice Aliança, Rio de Janeiro - Brasília, Revan - Editora da Universidade de Brasília, 1998, p. 26-31.

7 Ibidem, p. 138-142; Corcino Medeiros dos Santos, A produção das minas do Alto Perú e a evasão de prata para o Brasil, Brasília, Thesaurus Editora, 1998, p. 148-149; J. H. Parry, The Spanish seaborn empire, Berkley - Los Angeles - Londres, University of California Press, 1981 , p. 130 e 240.

8 Luís Ferrand de Almeida, Alexandre de Gusmão, o Brasil e o Tratado de Madrid (1735-1750), Coimbra, INIC, 1990, p. 29. 
podia prejudicar o império castelhano, e esse teria que ser o objectivo principal durante a guerra da Restauração (1640-1668).

A crise do século XVII sente-se com muita intensidade em Portugal. Com o fecho do comércio com Buenos Aires, no Brasil sofre-se uma apertada carência de moeda de prata. Além do mais há as dificuldades provocadas pela depreciação dos produtos coloniais dos trópicos, o açúcar e o tabaco. ${ }^{9}$ Depreciação que é parcialmente o resultado da concorrência das produções similares do Caribe que os holandeses lá desenvolvem depois da sua expulsão do Brasil. Crise que será muito funda, sem que a Coroa encontre respostas rápidas para resolver as dificuldades. A questão da fronteira sul do Brasil vê-se então recolocada no centro da política portuguesa: em Lisboa, os militares e o príncipe regente D. Pedro decidem instalar uma colónia portuguesa no Prata: será a Nova Colónia do Sacramento. Os espanhóis tinham desprezado a colonização da margem esquerda do Rio da Prata. ${ }^{10}$ Nela nada investiram, o que abriu o caminho para os portugueses. D. Manuel Lobo é nomeado governador do Rio de Janeiro e encarregado da instalação de nova fortaleza no Sul. Num território que se diz pertencer aos domínios portugueses. Como a viciada cartografia portuguesa intentava demonstrar. Mas as razões desse propósito serão sobremaneira políticas. Havia que garantir a segurança das costas brasileiras das tentações castelhanas de criar nelas estabelecimentos militares. O que para os castelhanos seria muito vantajoso, pois poderiam impedir com eficácia a aproximação ao Rio da Prata e, sobretudo, à prata. Que sempre era essa a questão principal.

Importante ainda era expandir a ocupação do Brasil ao Sul de São Vicente. Por esse tempo se iam fundando Paranaguá (1648), São Francisco do Sul (1658), Curitiba (1668), Nossa Senhora do Desterro, na Ilha de Santa Catarina (1677?), e Laguna (1688). Era o alargamento da presença portuguesa até ao Sul que tinha não poucos atractivos económicos, em especial a criação de gado. Pelas verdes pastagens da imensidade do Sul, muitos eram os bovinos e os equinos que se reproduziam e se cevavam sem pastores nem guardas. Nem proprietários. Gado que havia sido introduzido nas missões jesuíticas do Uruguay por 1634. Diz-se que é um gado chimarrão. ${ }^{11}$ Que se multiplicou incrivelmente e de um

9 Vitorino Magalhães Godinho, "As frotas do açúcar e as frotas do ouro", in Ensaios II. Sobre história de Portugal, Lisboa, Sá da Costa, 1974, p. 443.

${ }^{10}$ Mário Clemente Ferreira, O Tratado de Madrid e o Brasil Meridional, Lisboa, CNCDP, 2001 , p. 38.

${ }^{11}$ Luís Ferrand de Almeida, A diplomacia portuguesa e os limites meridionais do Brasil, vol. I (1493-1700), Coimbra, Faculdade de Letras, 1957, p. 97; Aurelio Porto, História das missões orientais do Uruguai, Rio de Janeiro, Imprensa Nacional, 1943, p. 163-164; Magnus 
modo natural no que ficou por isso chamada a Vacaria do Mar. ${ }^{12}$ Aproveitam-no os jesuítas das missões a oriente do Rio Uruguay. E também é esse o atractivo para o aproveitamento económico dessas pampas pelos portugueses e pelos castelhanos que nelas se vão chocar. Porque os couros e o sebo eram riquezas não desprezíveis no comércio internacional. Porque podiam exportar-se em grandes quantidades, o que ainda não era possível com a carne que ficava e que não havia como aproveitar. Em boa parte devido ao altíssimo preço do sal que decorria do seu monopólio no Brasil - suspeite-se também que não seriam nem abundantes nem boas as madeiras indispensáveis ao seu acondicionamento. ${ }^{13}$

A ordem régia e o regulamento para a fundação da Nova Colónia do Sacramento foram firmadas em Lisboa aos 18 de Novembro de 1678. E serão efectivados em 20 de Janeiro de 1680. ${ }^{14} \mathrm{Na}$ instalação da colónia no Prata não se cumpriu tudo o que estava consignado nas determinações reais. Em especial a fortaleza ficou sem o resguardo de uma outra fortificação que deveria ser construída diante dela, na ilha de São Gabriel. Mas se foi boa a decisão de estabelecimento da Nova Colónia, sem repouso se virá a mostrar a permanência de portugueses tão perto de Buenos Aires. Porque se é um facto que a margem esquerda do Rio da Prata não tinha tido importância para Castela até à instalação dos Portugueses, na mesma Castela não os queria por ali. ${ }^{15}$ Temia que se abrisse a porta ao comércio e à saca dos tesouros do Peru. Poucos meses decorridos sobre a primitiva instalação da fortaleza, uma expedição militar castelhana com 250 soldados e 3000 índios, comandada por Antonio de Vera Mujica a mando do governador da cidade portenha D. José de Garro tomou a praça e destruiu-a em 7 de Agosto de 1680. "Pelejou-se de uma e outra parte com grandíssima coragem, os Índios com grande alento para vencer, e os Portugueses com quase desespero até morrer." ${ }^{16}$ Grande foi a emoção em Portugal. E o regente príncipe

Mörner, Actividades politicas y económicas de los Jesuítas en el Río de La Plata, trad., Buenos Aires, Editorial Paidós, 1968, p. 24.

${ }^{12}$ Guilhermino Cezar, História do Rio Grande do Sul.Período colonial, Porto Alegre, Editôra Globo, 1970, p. 76-77.

${ }^{13}$ Myriam Ellis, O monopólio do sal no Estado do Brasil (1631-1801), São Paulo, Faculdade de Filosofia, Ciências e Letras, 1955, p. 193-198.

${ }^{14}$ Luís Ferrand de Almeida, "Sacramento, Colónia do", in Joel Serrão, coord., Dicionário de História de Portugal, Lisboa, Iniciativas Editoriais, vol. III, 1968; Idem, Origens da Colónia do Sacramento. O Regimento de D. Manuel Lobo (1678), separata da Revista da Universidade de Coimbra, vol. XXIX (1982).

15 J. Capistrano de Abreu, Capítulos de História Colonial (1500-1800), Rio de Janeiro, Sociedade Capistrano de Abreu, 1928, p. 250.

${ }^{16}$ Apud Luís Ferrand de Almeida, "Informação de Francisco Ribeiro sobre a Colónia do Sacramento", separata do Boletim da Biblioteca da Universidade de Coimbra, vol. XXII, p. 3. 
D. Pedro de imediato ameaça o reino vizinho com a guerra. Não a quer Carlos II, então rei de Castela. E em breve se chega a um tratado, que se chamou provisional, porque se esperava que fosse isso mesmo, transitório. Ocorreu em 1681. Retornava assim a Colónia do Sacramento à soberania portuguesa. Em definitivo não se conseguiu resolver nada. A conferência de Elvas-Badajoz de 1681-1682 não chegou a um resultado aceitável por ambas as partes. Uma vez mais. Porém, o Tratado Provisional, se consentia o estabelecimento no Prata proibia aos portugueses a actividade comercial. Nem na Nova Colónia se permitia construções duradouras e permanentes. ${ }^{17}$

Agora o rei português D. Pedro II vai decidir empurrar a colonização do Sul: para o que precisava de gente. Mas onde arranjá-la? Nas regiões mais povoadas e mais pobres de Portugal, no Norte litoral, no Minho.É a decisão de inícios dos anos Noventa, quando Castela está empenhada e talvez distraída com a guerra da Liga de Augsburgo (1688-1697). Muito em breve se vê que a solução pode afinal consistir em levar gente das Ilhas, em especial dos Açores. Aí, devido à numerosa população e à escassez de recursos - agravada por calamidades naturais frequentes como erupções vulcânicas e tremores de terra, se intentaria recrutar famílias para migrarem para a América do Sul. Gente laboriosa, esforçada, que saberia cultivar e aproveitar as terras e multiplicar os gados. Assim o requeria ao rei o governador da praça D. Francisco Naper de Lencastre. Com o seu governo cresce a Nova Colónia, vindo gente do Brasil e atraindo índios. E com os primeiros casais de lavradores emigrados. Por 1692 eram já uns 1000 os habitantes do Sacramento. E por fins do século, 1699-1700, chegariam aos $1500 .{ }^{18}$ Alguns artesãos se estabelecem, vêm também carros, ferramentas, arados, materiais de construção e apetrechos necessários ao funcionamento de moinhos. O aproveitamento da campanha continuava a ser importante para a população do Sacramento. Sobretudo o aproveitamento dos couros, do sebo e a preparação das carnes secas e salgadas. ${ }^{19}$ A acção do governador D. Francisco Naper de Lencastre foi muito relevante apesar de muito contrariada pelos seus adversários. Agora também se iam introduzindo os cereais, que tanto importavam para alimentar a guarnição militar e os povoadores. Porque a ocupação das terras circundantes estava a realizar-se. Porque se impunha

17 "Tratado Provisional” in Luís Ferrand de Almeida, A diplomacia portuguesa e os limites meridionais do Brasil, vol. I (1493-1700), p. 426-431.

${ }^{18}$ Luís Ferrand de Almeida, "Informação de Francisco Ribeiro sobre a Colónia do Sacramento, p. 10; Luís Ferrand de Almeida, "Casais e lavradores na Colónia do Sacramento (1680-1705)", separata da Revista Portuguesa de História, tomo XXX (1995), p. 32.

${ }^{19}$ Luís Ferrand de Almeida, "Informação de Francisco Ribeiro sobre a Colónia do Sacramento", p. 10. 
"que se descobrisse todas aquelas campinas, com a notícia certa de todos os seus Rios, Portos, enseadas, utilidades, conveniências, demarcações." De que será encarregado o governador Sebastião da Veiga Cabral na transição entre os dois séculos (1699-1705). ${ }^{20}$

Uma vez por outra se ia negociando com Buenos Aires, o que era defeso, porque um dos principais propósitos para a fundação da Nova Colónia tinha sido captar a prata que aí chegava. Mas agora percebia-se que a instalação militar portuguesa, só por si, não podia sobreviver. Porque os castelhanos não deixavam de guardar as suas posições no arroio de São João desde 1683 (a quatro léguas da Colónia) e erguendo o forte de Santo Domingo Soriano cerca do rio Uruguay, na embocadura do rio Negro. ${ }^{21}$ Como resposta possível, havia que resguardar a Colónia com uma população que estivesse bem radicada e que pudesse produzir o que comia e aproveitar as riquezas agrícolas e pecuárias da região. Que se anteviam muitas: destaca-se a possibilidade de cultivo do trigo - o que sempre era muito estimado pelos europeus - e outros cereais. Hortaliças e ervas de cheiro, muitos frutos, inclusivamente para fazer vinho e azeite - o que seria ilusório. Inumeráveis cabeças de gado, vacum e cavalar como já se explorava. Possibilidades que se revelavam imensas, ao que nos dizem os testemunhos. ${ }^{22}$ Abria-se a expectativa de se gerar grandes riquezas.

Gente para a Colónia do Sacramento havia que atraí-la e que instalá-la. Que a terra ficasse ocupada e assim melhor defendida. Com muito cuidado, para não alarmar os castelhanos da praça fronteira. $\mathrm{O}$ aumento da população do Sacramento e dos interesses aí possíveis é um dado importante de fins do século XVII - princípios do século XVIII. Tempo em que começa o comércio de couros para os portos do Brasil e de Portugal. ${ }^{23}$ Por 1701 é a cessão do Sacramento à coroa portuguesa pelo Tratado de 18 de Junho. Mas as alianças internacionais

${ }^{20}$ Luís Ferrand de Almeida, A Colónia do Sacramento na época da Sucessão de Espanha, Coimbra, Faculdade de Letras, 1973, p. 89-93; Sebastião da Veiga Cabral, Descrição Corogràfica e Coleção Histórica do Continente da Nova Colónia da Cidade do Sacramento, separata da Revista del Instituto Histórico y Geográfico del Uruguay, tomo XXIV, Montevideu, Imprenta Nacional (1965), p. 18: apesar da leitura defeituosa tem de utilizar-se esta publicação, enquanto se aguarda pela transcrição efectuada por Luís Ferrand de Almeida.

${ }^{21}$ Luís Ferrand de Almeida, "Informação de Francisco Ribeiro sobre a Colónia do Sacramento", p. 21 e 41-42; Luis Enrique Azarola Gil, Los orígenes de Montevideu. 1607-1749, Buenos Aires, Librería y Editorial "La Facultad", 1933, p. 82.

${ }^{22}$ Sebastião da Veiga Cabral, Descrição Corogràfica e Coleção Histórica do Continente da Nova Colónia da Cidade do Sacramento, p. 46-48.

${ }_{23}$ Jaime Cortesão, Alexandre de Gusmão e o Tratado de Madrid, Lisboa, Livros Horizonte, 1984, vol. II, p. 514. 
vão levar outra vez à sua perda, abandono e, uma vez mais, destruição. ${ }^{24}$ Não haverá então continuidade na ocupação, porque a conflituosa sucessão no trono de Espanha vai trazer a guerra e a destruição depois do cerco de 1704-1705. É o fim de um período, em que ficou demonstrado que o Sacramento tinha possibilidades de manutenção e mesmo de crescimento, desde que estivesse bem guardado pelo que tocava ao aspecto militar e melhor povoado e aproveitado pelo que tocava ao económico. Em especial pelo comércio dos couros. ${ }^{25}$ De 1705 a 1715 é a grande pausa, sem a presença portuguesa - outros interesses se manifestam, como os dos franceses do "assento" que são autorizados a vender escravos negros em Buenos Aires e aí carregam couros. Com essa demanda acrescida se dá a extinção do gado chimarrão na banda bonaerense. ${ }^{26} \mathrm{Nem}$ assim haverá desistência por parte da coroa portuguesa. Porque sempre se soube que havia que recomeçar. ${ }^{27} \mathrm{E}$ porque os motivos da presença portuguesa no Rio da Prata se mantinham: era a tentativa de levar o Brasil até ao Prata, pensado como fronteira natural. $\mathrm{O}$ que não aceitavam os espanhóis, que sempre se opuseram a isso. Os membros do Conselho de Índias instam com o novo monarca Filipe $\mathrm{V}$ para que "não permita o mais leve assentimento nem consentimento a tal pretensão, para seu maior serviço, bem universal destes Reinos e conservação daqueles (do Perú)." ${ }^{28}$ Porque se desde sempre o propósito português era o acesso à prata americana, ainda se sabia que aquele território era incomparável de comodidade, fertilidade e riqueza. ${ }^{29}$

O Tratado de Utrecht entre Portugal e Espanha foi assinado a 6 de Fevereiro de 1715. Os representantes de Portugal nas negociações obtiveram que se registasse a devolução da Colónia do Sacramento aos Portugueses. E com a Colónia o seu território. Todavia, não ficou claro o que se entendia por território. Além disso, abria-se a possibilidade de substituir o Sacramento por um "equivalente", qual fosse o território equivalente não se indicou. Tudo isto vai causar muitas dificuldades diplomáticas e militares. Porque os governantes espanhóis adoptaram uma interpretação muito restritiva do termo

${ }^{24}$ Ibidem, p. 208 e 287-288.

${ }^{25}$ Luís Ferrand de Almeida, A Colónia do Sacramento na época da Sucessão de Espanha, p. 117-124.

${ }^{26}$ Magnus Mörner, Actividades politicas y económicas de los Jesuítas en el Río de La Plata, p. 122.

${ }^{27}$ Luís Ferrand de Almeida, A Colónia do Sacramento na época da Sucessão de Espanha, p. 294.

${ }^{28}$ Jaime Cortesão, Alexandre de Gusmão e o Tratado de Madrid, Lisboa, vol. I, p. 204-205.

${ }^{29}$ Sebastião da Veiga Cabral. Descrição Corogràfica e Coleção Histórica do Continente da Nova Colónia da Cidade do Sacramento. 
"território". Para o rei português o território era a margem norte do Rio da Prata, nada menos; para o rei espanhol seria somente a área que ficava no interior de uma circunferência ao redor da fortaleza, marcada por um tiro de canhão. ${ }^{30}$ Por isso, sem embargo da devolução do Sacramento, em 1716, a vigilância militar e os condicionalismos económicos mantiveram-se. Porque os portenhos, que detinham boa parte do contrabando que se praticava na Colónia, se queixavam de que havia fugas aos direitos fiscais e de que a prata por ali se encaminhava para o Brasil. Em especial os vizinhos membros do cabildo (vereação) da cidade, faziam-se bem ouvir pelo governador. ${ }^{31}$ Também os padres jesuítas das missões tinham muito má vontade aos portugueses aos quais ali sempre se opuseram. ${ }^{32}$

Dos jesuítas também se queixa o governo português, porque os missionários incitavam os índios contra os portugueses, índios que eles tinham agrupados nas suas reduções. Se o padre geral da Societas Jesu proíbe que inquietem os portugueses, os jesuítas espanhóis querem o seu confinamento à fortaleza, porque noutro caso "seriam donos de todas as vacas daquelas terras, sacando navios carregados de couros." ${ }_{33}$ Porque os religiosos querem-se como senhores das riquezas da Vacaria, para eles e para os seus índios.

Os Portugueses obstinam-se em desenvolver a Colónia - que o mesmo era segurá-la: de Trás-os-Montes (no Norte interior de Portugal), chegam 61 famílias, com 297 pessoas, em 1718. No Sacramento recebem terras, apetrechos agrícolas, sementes e bestas de trabalho. Gente que é dito entender de agricultura. Em Abril desse ano a praça tinha já 111 famílias e 1040 habitantes. ${ }^{34}$ Em 1722 seriam 350 os moradores; no porto entraram 11 embarcações que

${ }^{30}$ Luís Ferrand de Almeida, "A Colónia do Sacramento e a formação do Sul do Brasil”, in Páginas dispersas. Estudos de História Moderna de Portugal, Coimbra, Faculdade de Letras, 1995, p. 172; Luís Ferrand de Almeida, Alexandre de Gusmão, o Brasil e o Tratado de Madrid (1735-1750), p. 7-8.

${ }^{31}$ Paulo Possamai, A vida quotidiana na Colónia do Sacramento. Um bastião português em terras do futuro Uruguai, Lisboa, Livros do Brasil, 2006, p. 83-88.

${ }^{32}$ Jaime Cortesão, Alexandre de Gusmão e o Tratado de Madrid, vol. II, p. 515.

${ }^{33}$ Magnus Mörner, Actividades politicas y económicas de los Jesuítas en el Río de La Plata, p. 122.

${ }^{34}$ Luís Ferrand de Almeida, "A Colónia do Sacramento e a formação do Sul do Brasil", p. 172; Jonathas da Costa Rego Monteiro, A Colónia do Sacramento 1680-1777, Porto Alegre, Livraria do Globo, 1937, II vol., p. 70-72. 
saíram carregadas de couros e prata.$^{35}$ Começara uma notável expansão dos portugueses pela campanha. Vêm mais casais de lavradores dos Açores ${ }^{36}$

O contrabando desenvolve-se: no triénio de 1719-1721 saíram dali imensas quantidades de prata (650 000 cruzados) e muitíssimos couros (110 000). Isto pelo que ficou registado, que os particulares também enviaram as suas partes. Muitas embarcações frequentam o porto - trazem mercadorias do Brasil e retornam carregadas de prata e couros. Desenvolvem-se também as sementeiras de trigo. A Colónia ia em grande aumento, dizem os moradores por 1730; querem que se estabeleça a vida municipal, sendo vila ou cidade; ao governador competiam por então os deveres do juiz. Além disso necessitavam de um médico - mesmo se se dizia que a terra era muito saudável. ${ }^{37}$ No ano seguinte o padre cartógrafo Diogo Soares confirma que o número das famílias e casais cresce todos os dias. ${ }^{38}$ Por $1734-1735$ haveria 2600 pessoas, vivendo em 327 casas. Nos arredores desenvolviam-se as culturas e, sobretudo, multiplicava-se o gado. ${ }^{39}$ Sacramento podia agora ser dito um verdadeiro "foco de contrabando" - "porta de escape do comércio de Buenos Aires", como se divulgou também. ${ }^{40}$ E em muitos produtos, nomeadamente de abastecimento de víveres para a Colónia que deles carecia. Enquanto produtos europeus e brasileiros era a contrapartida da oferta portuguesa. ${ }^{41}$ Em que estavam interessadas gentes não apenas de Buenos Aires mas de Santa Fé e de Corrientes.

A exportação anual por Sacramento chegará à enormidade de 400000 ou 500000 couros anuais. ${ }^{42}$ Sem embargo, falhou o estabelecimento da cidade de São Filipe e Santiago de Montevideu pelos portugueses no ano de $1723 .{ }^{43}$

${ }^{35}$ Jonathas da Costa Rego Monteiro, A Colónia do Sacramento 1680-1777, I vol., p. $180-181$.

${ }^{36}$ Walter Piazza, A epopeia açórico-madeirense (1746-1756), 2a ed., Funchal, Região Autónoma da Madeira, 1999, p. 39-45.

${ }^{37}$ Luís Ferrand de Almeida, A Colónia do Sacramento na época da Sucessão de Espanha, p. 75 .

${ }^{38}$ Jonathas da Costa Rego Monteiro, A Colónia do Sacramento 1680-1777, II vol., p. 78-82.

${ }^{39}$ Luís Ferrand de Almeida, "A Colónia do Sacramento e a formação do Sul do Brasil", p. 173-174.

${ }^{40}$ C. Correa de Luna apud Luís Ferrand de Almeida, Alexandre de Gusmão, o Brasil e o Tratado de Madrid (1735-1750), p. 10; José Luís Romero, Breve historia de la Argentina, p. 32.

${ }^{41}$ Isabel Paredes, "Comercio y contrabando entre Colónia del Sacramento y Buenos Aires en el período 1739-1762", in Colóquio Internacional Território e Povoamento - A presença portuguesa na região platina, Lisboa, Instituto Camões, 2004, p. 13.

${ }^{42}$ Jaime Cortesão, Alexandre de Gusmão e o Tratado de Madrid, vol. II, p. 517 e 521.

${ }^{43}$ Jonathas da Costa Rego Monteiro, A Colónia do Sacramento 1680-1777, vol. I, p. 184-190. 
Tentativa de alargar o assentamento na margem do Prata. Cuja intenção "consistia somente em tomar posse do que pertencia à sua coroa [portuguesa], sem romper a paz e boa amizade que tinha com o rei católico." ${ }^{44} \mathrm{O}$ que se escrevia pertencer à coroa do rei de Portugal resultava ser a margem esquerda do Rio da Prata, nada menos... Logo em seguida foram os espanhóis a conseguir a criação da cidade de Montevideu com a colaboração da vereação de Buenos Aires e a chegada de imigrantes das Canárias. O acto de fundação jurídica e escolha dos vereadores e demais autoridades locais datará de 24 de Dezembro de $1729 .{ }^{45}$

Entretanto a ganadaria tem uma forte procura nas Minas Gerais. O que explica por que cerca de 1727 se abram caminhos para Curitiba e para São Paulo para que vacuns, muares e cavalos cheguem aos compradores nas Minas. Mas esses caminhos também seriam um perigo porque por eles poderiam por igual penetrar os espanhóis. ${ }^{46}$

A prosperidade da Nova Colónia no Prata vai ser interrompida aproveitando um incidente diplomático menor ocorrido em Madrid, em 1735. Um criminoso refugiou-se na embaixada de Portugal ajudado por servidores do embaixador de D. João V. O qual não lhe concedeu asilo. Mas as relações diplomáticas quando a embaixada foi invadida, ficaram perturbadas e inclusivamente romperam-se. Como retaliação as tropas de Buenos Aires cercam a Colónia. Tinha o governador de Buenos Aires recebido ordem do ministro de Filipe V D. José Patiño: "que sem esperar a que formalmente se declare a Guerra com os Portugueses e só em virtude desta ordem, se surpreenda, tome e ataque a Cidade e Colónia do Sacramento, despojando e deitando fora dela os Portugueses..." ${ }^{47}$

As queixas contra os portugueses e contra as suas prósperas actividades económicas explicam a animosidade dos portenhos. ${ }^{48}$ Seguir-se-ão 22 meses de brava resistência dos moradores. Habitantes da Colónia havia espanhóis, que têm de se retirar aquando do sítio, sob pena de morte como traidores. ${ }^{49}$

${ }^{44}$ Luis Enrique Azarola Gil, Los orígenes de Montevideu. 1607-1749, p. 80.

${ }^{45}$ Ibidem, p. 92, 116-117 y 125 y 258-261; Luis Enrique Azarola Gil, Crónicas y linajes de la gobernación del Plata. Documentos inéditos de los siglos XVII y XVIII, Buenos Aires, J. Lajouane \& Cia. - Editores, 1927, p. 33-34.

46 Jonathas da Costa Rego Monteiro, A Colónia do Sacramento 1680-1777, II vol., p. 80-82.

${ }^{47}$ Apud Luís Ferrand de Almeida, Alexandre de Gusmão, o Brasil e o Tratado de Madrid (1735-1750), p. 21; Jaime Cortesão, Alexandre de Gusmão e o Tratado de Madrid, vol. III, p. 551-556.

48 Jaime Cortesão, Alexandre de Gusmão e o Tratado de Madrid, vol. III, p. 559-560.

${ }^{49}$ Silvestre Ferreira da Silva, Relação do Sítio da Nova Colônia do Sacramento, Nota Preliminar de Brasil Bandecchi, Colecção da Revista de História. São Paulo: 1977, p. 73. 
Uma armada saída de Lisboa para combater no Prata e mesmo conquistar Montevideu não vai chegar ao seu destino. Mas isso agora já não seria tão importante, porque fazia já parte de uma estratégia que implicava o Sul do Brasil, tanto quanto o Prata. Dada a impossibilidade de ir tomar Montevideu, dirige-se ao Rio Grande e instala em 1737 uma fortaleza, com o nome de Jesus-Maria-José na entrada da Lagoa dos Patos - que depois como Rio Grande de São Pedro seria elevada a vila com município próprio em 1747. Foi seu fundador, comandante e principal estratega o brigadeiro José da Silva Pais. ${ }^{50}$

Mas por fim, se a fortaleza do Sacramento soube resistir, os haveres dos moradores sofreram uma terrível ruína. Muito em especial os campos e culturas na campanha. Vê-se que não há remédio: a Espanha sempre faria por perturbar a sua posse, "e para isso terá sempre o pretexto do contrabando." Porque se tratava de um "espaço fronteiriço aberto" no interior de uma área que pode designar-se por "complexo portuário rio-platense." ${ }^{51}$ Havia que resolver esta dificuldade que ameaçava a vida da guarnição militar e que impunha enormes custos para a manter. O obstáculo jurídico estava no velho Tratado de Tordesilhas (1494), que mesmo sem se cumprir continuava a vigorar. Havia possibilidades diplomáticas de resolver a questão com a troca do Sacramento por um equivalente - como constava do Tratado de Utrecht de 6 de Fevereiro de 1715. Mas as propostas espanholas são consideradas insuficientes pelo soberano português, e não mostram disponibilidade por parte de Espanha para considerar o problema na sua totalidade. Que era o das fronteiras das Américas Portuguesa e Espanhola. ${ }^{52}$

Havia que esperar, pois, que chegasse tempo em que a proposta pudesse ser bem recebida. Para o que se requeria conservar - mesmo a grande custo a praça do Sacramento. Valorizá-la era aumentar o equivalente que haveria de ser proposto. ${ }^{53} \mathrm{E}$ não podiam olvidar os peninsulares que os interesses ingleses se mostravam muito vivos - a Inglaterra conseguira pelo Tratado de Utrecht introduzir-se com navios do assento de escravos da South Sea Company no comércio do Rio da Prata. O que figurava uma ameaça. Portugal e Espanha

${ }^{50}$ Apud Luís Ferrand de Almeida, Alexandre de Gusmão, o Brasil e o Tratado de Madrid (1735-1750), p. 24-25; Apud Aurelio Porto, História das missões orientais do Uruguai, p. 372-375; Walter F. Piazza, O Brigadeiro José da Silva Pais estruturador do Brasil meridional. Florianópolis: Editora da UFSC, 1988, p. 109-117.

${ }^{51}$ D. Luís da Cunha, Instruções Políticas, Lisboa, CNCP, 2001, p. 328-330; Fabrício Pereira Prado, "Colônia do Sacramento: a situação na fronteira platina no século XVIII", in Horizontes Antropológicos, Porto Alegre, vol. I, no 19, Julho 2003, p. 83-86.

${ }_{52}$ Luís Ferrand de Almeida, Alexandre de Gusmão, o Brasil e o Tratado de Madrid (1735$-1750)$, p. 8-9.

${ }^{53}$ Jaime Cortesão, Alexandre de Gusmão e o Tratado de Madrid, vol. III, p. 572 e 782. 
teriam que convir entre si uma solução para garantir os seus domínios coloniais na América do Sul - que muitos supunham em risco..$^{54}$

Agora a grande atracção do litoral sul torna-se não o ouro - que muito pouco ou nenhum se recolhe por aí - mas a enorme riqueza pecuária, em animais de corte e de tracção. E para ocupar a terra vêm os casais de colonizadores das ilhas da Madeira e dos Açores ${ }^{55}$ Alguns já retornados da Colónia. E mais chegarão depois. ${ }^{56} \mathrm{O}$ que havia de fazer-se sempre com grande reserva, senão em segredo. Para não provocar as desconfianças dos espanhóis, vigilantes para com tudo o que respeitasse qualquer aproximação ao Prata. Porque havia que incrementar a população em direcção à margem esquerda do Rio Uruguay. ${ }^{57} \mathrm{Sem}$ isso a defesa do Sacramento ou a negociação das fronteiras seria impossível. Tanto como assegurar o domínio no Sul do Brasil, que se queria colonizar. Por isso ainda a política de enviar famílias a povoar as terras que se pretendia desenvolver: Ilha de Santa Catarina, Rio Grande, Laguna e outras mais. Terras ocupadas e cultivadas teriam muito mais fácil defesa ${ }^{58}$ Importante ainda era a proximidade para fazer chegar socorros militares. Santa Catarina estava a uns 7 dias de Sacramento, Rio de Janeiro ficava a $14 .{ }^{59} \mathrm{O}$ conhecimento da terra, tão rigoroso quanto possível, é desejado pelo rei. Por isso os padres jesuítas matemáticos encarregados do desenho dos mapas do Novo Atlas da América Portuguesa tinham ido à Nova Colónia em 1731. O Padre Diogo Soares desenhara um plano da cidade e um outro plano de uma nova fortificação. A presença destes cartógrafos não resulta do acaso. ${ }^{60}$

D. João V empreende tentar uma negociação tendo como princípio a ocupação efectiva - é o acolhimento do instituto jurídico do uti possidetis. A boa possessão seria aquela em que cada um já estivesse. Não mais se quer recorrer

${ }^{54}$ Ibidem, p. 757-761; Stanley J. Stein y Barbara H. Stein, Plata, comercio y guerra. España y América en la formación de la Europa moderna, p. 221; Fabrício Pereira Prado, "Colônia do Sacramento: a situação na fronteira platina no século XVIII", p. 87-88.

${ }^{55}$ Guilhermino Cezar, História do Rio Grande do Sul. Período colonial, p. 100.

${ }^{56}$ Virgínia Rau (e outros), "Dados sobre emigração madeirense para o Brasil no século XVIII", Coimbra, V Colóquio Internacional de Estudos Luso-Brasileiros, Coimbra, 1965, p. 5-14.

${ }^{57}$ Guilhermino Cezar, História do Rio Grande do Sul. Período colonial, p. 105.

${ }^{58}$ General João Borges Fortes, Os Casais Açorianos. Presença lusa na formação do Rio Grande do Sul, $2^{\text {a }}$ ed., Porto Alegre, Martins Livreiro Editor, 1978, p. 66.

${ }^{59}$ Frédéric Mauro, "Political and economic structures of empire, 1580-1750", in Leslie Bethel, Colonial Brazil, Cambridge - New York - New Rochelle - Melbourne - Sydney, Cambridge University Press, 1987, p. 62-63.

${ }^{60}$ André Ferrand de Almeida, A formação do espaço brasileiro e o projecto do Novo Atlas da América Portuguesa (1713-1748), Lisboa, CNCDP, 2001, p. 116-117. 
ao direito histórico, o que significava reconhecer que vigorava em plenitude o tratado assinado em Tordesilhas. A isso se juntava que o desenho das fronteiras que se queriam estratégicas se deveria fazer por acidentes naturais, quando fosse possível. ${ }^{11}$ Se não naturais, defensáveis. O que se desejava eram "limites certos e invariáveis" (como rios e cimos de montes) e não mais linhas imaginárias. ${ }^{62}$ Havia que fixar "o equilíbrio das soberanias territoriais." ${ }_{63}$ Os objectivos de Espanha consistiam em "tirar-lhes a Colónia e o famoso contrabando do rio da Prata... a Colónia não lhes aproveita e nos destrói”, pensava o governo de Madrid. ${ }^{64}$ Porque "Colónia e actividade ilícita eram sinónimos na quase totalidade dos casos." ${ }^{65}$

A decisão estaria tomada por D. João V: impunha-se mesmo sair da Colónia para obter a paz. A rainha espanhola era agora a portuguesa Maria Bárbara de Bragança, mulher de Fernando VI, inteligente e activa filha do rei português. Que bem queria ver resolvidas as pendências entre Portugal e Espanha. ${ }^{66}$ Teria que haver cedências, negociar-se-iam compensações: as conversações vão durar quase três anos. Dirigem-nas em Portugal o brasileiro nato Alexandre de Gusmão e em Madrid o embaixador visconde Tomás da Silva Telles; pela Espanha o ministro D. José de Carvajal y Lancaster. A este, há que convencê-lo que o Tratado de Tordesilhas não pode continuar a ser considerado como ponto de partida.$^{67}$ As conversações avançam, e propõe-se que Portugal deixe a Colónia do Sacramento e que em troca receba a região dos Sete Povos das missões jesuíticas na margem esquerda do Rio Uruguay. A região das missões era de facto um equivalente aceitável para justificar o abandono da Colónia. Até porque afastava os Castelhanos dos caminhos que podiam conduzir às riquezas das Minas. A maior largura do território do Sul do Brasil seria o resultado a obter: com isso se dava "hum fundo grande ao Estado do Brasil." ${ }_{68}$ Além disso, convinha essa parte das fronteiras do Sul como propunha de

${ }^{61}$ Luís Ferrand de Almeida, Alexandre de Gusmão, o Brasil e o Tratado de Madrid (1735-1750), p. 40.

${ }^{62}$ Apud Luís Ferrand de Almeida, Alexandre de Gusmão, o Brasil e o Tratado de Madrid (1735-1750), p. 42.

${ }_{63}^{63}$ Jaime Cortesão, Alexandre de Gusmão e o Tratado de Madrid, vol. I, p. 206.

${ }^{64}$ Ibidem, vol. III, p. 785.

${ }^{65}$ Isabel Paredes, "Comercio y contrabando entre Colónia del Sacramento y Buenos Aires en el período $1739-1762$ ", p. 7.

${ }^{66}$ Luís Ferrand de Almeida, Alexandre de Gusmão, o Brasil e o Tratado de Madrid (1735-1750), p. 35; José Luís Gómez Urdañez, Fernando VI, Madrid, Alianza Editores, 2001, p. 87-88.

${ }^{67}$ Jaime Cortesão, Alexandre de Gusmão e o Tratado de Madrid, vol. IV, p. 818.

${ }^{68}$ Alexandre de Gusmão, Collecção de varios escritos ineditos politicos e litterarios, Porto, na Typographia de Faria Guimarães, 1841, p. 152-168; Sebastião da Veiga Cabral, Descrição 
Lisboa o secretário do rei, Alexandre de Gusmão. E seria esse o resultado final do tratado firmado em Madrid em 14 de Janeiro de 1750, com data de 13 de Janeiro.$^{69} \mathrm{O}$ que se apresentava com um tremendo custo humano: vinte e nove a trinta mil índios, pensa-se, teriam que ser deslocados com os missionários para irem povoar outras terras (artigo XVI) ${ }^{70}$. Ainda por cima, não seria fácil encontrá-las com a qualidade das que agora deviam ser abandonadas.

Outras correcções fronteiriças se introduzem no Oeste (nas regiões mineiras de Mato Grosso) e no Norte interior (no Amazonas)..$^{71}$ Mas as de maior impacto e futuro foram as do Rio da Prata. Para os espanhóis era o mais importante: "todo o nosso interesse em tirar essa colónia que nos faz perder o Perú...", escreve um ministro em $1754 .^{72}$ Porém, não foram as cláusulas do tratado depois bem recebidas por muitos: a uns, porque retirava a presença portuguesa do Prata; a outros porque ia deslocar povoações das missões índias, a que se opunham os jesuítas. No Rio Grande tinha-se preparado a transferência de casais das Ilhas para o território das missões. ${ }^{73}$ Mas isso já não aconteceu. O governo português pretendia ampliar o território para o Oeste, até ao Rio Uruguay. Como contrapartida ao esperado desenvolvimento da economia do Prata. E segurando assim as fronteiras do Brasil. O que não ocorreu então. Haveria de vir a guerra com os jesuítas e com os índios para impor o cumprimento do tratado. Seria a "guerra guaranítica" - como se lhe chamou. Que ia resolver-se em duas campanhas militares, em 1753-1754 e em 1755-1756. Porque os índios das reduções e os jesuítas seus comandantes militares vão lutar com bravura e tenacidade para impedir a concretização do disposto no tratado. ${ }^{74} \mathrm{Com}$ o apoio

Corogràfica e Coleção Histórica do Continente da Nova Colónia da Cidade do Sacramento, p. 200-203.

${ }^{69}$ Luís Ferrand de Almeida, Alexandre de Gusmão, o Brasil e o Tratado de Madrid (1735-1750), p. 43; texto do tratado in José Carlos de Macedo Soares, Fronteiras do Brasil no Regime Colonial, Rio de Janeiro, Livraria José Olympio Editora, 1939, p. 141-157; Jaime Cortesão, Alexandre de Gusmão e o Tratado de Madrid, vol. IV, p. 912-929.

${ }^{70}$ Ibidem, p. 152; Juan José Arteaga, Breve historia contemporânea del Uruguay. México: Fundo de Cultura Económica, 2000, p. 23.

${ }^{71}$ Jaime Cortesão, Alexandre de Gusmão e o Tratado de Madrid, vol. III, p. 783.

${ }^{72}$ Pedro Octávio Carneiro da Cunha, "Política e administração de 1640 a 1763", in Sérgio Buarque de Holanda (direcção), História da Civilização Brasileira, tomo II, p. 49.

${ }^{73}$ Guilhermino Cezar, História do Rio Grande do Sul. Período colonial, p. 131-132.

${ }^{74}$ J. Capistrano de Abreu, Capítulos de História Colonial (1500-1800), p. 257-258; in Francisco Adolfo de Varnhagen, História Geral do Brasil, $5^{\text {a }}$ ed., São Paulo, Edições Melhoramentos, 1956, tomo Quatro, p. 169-170; Guilhermino Cezar, História do Rio Grande do Sul. Período colonial, p. 149-157; Rejane da Silveira Several, A Guerra Guaranítica, Porto Alegre, Martins Livreiro Editor, 1995, p. 116-148; André Ferrand de Almeida, A formação do espaço brasileiro e o projecto do Novo Atlas da América Portuguesa (1713-1748), p. 166-171. 
de muitos outros jesuítas que também estavam contra a evacuação. ${ }^{75}$ Tratado de Madrid que por fim não se cumpriu. Mas cujas orientações se mantiveram vivas para os governos que as tinham firmado, em especial para o governo português.

Houve que decidir, pois, a revogação do Tratado. Isso foi feito pelo Tratado do Pardo, de 12 de Fevereiro de $1761 .{ }^{76} \mathrm{O}$ rei era agora Carlos III, que se sabia contrário ao Tratado de Madrid. E tudo voltou ao anterior, no papel. Porque logo no ano de 1762 a Colónia foi assaltada e perdida pelos Portugueses. O governador de Buenos Aires, D. Pedro de Cevallos, encarregou-se de mais esse cerco. ${ }^{77}$ A que logo se segue a restituição fixada pelo Tratado de Paris, de 1763, que não foi totalmente cumprida pelos Espanhóis - e ficava e continuava sem solução o problema do território.

Entretanto prosseguia a conquista e ocupação do Rio Grande em 1763, o que mostra que esse era um dos pontos de importância estratégica que os vizinhos queriam dominar. ${ }^{78}$ E sempre o contrabando na Nova Colónia, que ia irritando os governadores de Buenos Aires - mesmo quando com isso aproveitavam. Em 3 de Junho de 1777 D. Pedro de Cevallos, agora vice-rei, cercou a Nova Colónia. O comandante português determinou a entrega da fortaleza do Sacramento "antes que os seus habitantes e defensores perecessem de fome, e antes que o inimigo rompesse com o fogo." 79 Em seguida o general espanhol ordenou a sua demolição e fez cegar o porto. ${ }^{80} \mathrm{O}$ Tratado de Santo Ildefonso de 1 de Outubro desse ano, com Portugal reconhecendo a derrota e o consequente abandono, põe fim ao percurso da Colónia do Sacramento em mãos

${ }^{75}$ Magnus Mörner, Actividades politicas y económicas de los Jesuítas en el Río de La Plata, p. 136.

${ }^{76}$ José Carlos de Macedo Soares, Fronteiras do Brasil no Regime Colonial, p. 158-161; Juan José Arteaga, Las consecuencias del Tratado de Madrid en la desarticulación de la frontera demográfica de la Banda Oriental, Montevideu, Centro de Difusión del Libro, 1999, p. 339.

${ }^{77}$ In Francisco Adolfo de Varnhagen, História Geral do Brasil, $5^{\text {a }}$ ed., tomo Quatro, p. 206-224; Ricardo Lesser, La última llamarada: Cevallos, primer virrey del Río de la Plata, Buenos Aires, Biblos, 2005, p. 65-67.

${ }^{78}$ Ibidem, p. 186-205; Guilhermino Cezar, História do Rio Grande do Sul. Época colonial, p. 170-172; Devassa sobre a entrega da Villa do Rio Grande ás tropas castelhanas 1764, Rio Grande, Bibliotheca Rio-Grandense, 1937, p. 7-11.

79 Juan Beverina, La expedición de Don Pedro de Cevallos (en 1776-1777), reed., Buenos Aires, Editorial Rioplatense, 1977; Pedro Pereira Fernandes de Mesquita, Relación de la conquista de la Colónia por D. Pedro de Cevallos y descripcion de la ciudad de Buenos Aires, ed. Fernando O. Assunção, Buenos Aires, Academia Nacional de la Historia, 1980, p. 23.

${ }^{80}$ Ángel Sanz Tapia, El final del Tratado de Tordesillas: la expedición del virrey Cevallos al Río de la Plata, Valladolid, Junta de Castilla y Léon - Sociedad V Centenário del Tratado de Tordesillas, 1994, p. 343. 
de Portugueses.$^{81}$ Fundação que se deveu e perdeu pela ambição desmesurada que era a da sua criação, a de levar os domínios portugueses até ao Rio da Prata. Que seria a fronteira desejável. No entanto, ameaçando o monopólio argentífero das Î́ndias de Castela...

Não foi só a fortaleza, nem as muitas vezes referida ameaça da presença inglesa na região que podia representar um perigo real para os espanhóis. O governo de Madrid compreendeu que não podia deixar que se estendesse mais a presença portuguesa no Sul do Brasil e que se aproximasse do Rio da Prata. Porque a reconquista e a colonização do Continente do Rio Grande estava em marcha. A instalação dos casais aumentava a população e também os recursos. Os territórios perdidos em 1765 tinham-se ido recobrando. Na Espanha temeu-se mesmo por Maldonado e por Montevideu.$^{82}$ Porque a estratégia para 0 Rio da Prata também só se concebe com a indispensável articulação com o Rio Grande. Contrária aos ocupantes espanhóis estava a organização de guerrilhas que ia erodir as suas forças de ocupação.$^{83} \mathrm{E}$ sabia-se que com a possibilidade de ajuda militar mais próxima e mais rápida à Colónia as coisas se tornariam muito mais difíceis.

Também por isso mesmo com a reconquista do Rio Grande se perdeu a Ilha de Santa Catarina (em 28 de Fevereiro de 1777) e provocou a demolição de Sacramento (3 de Junho de 1777), que tudo se mistura ainda com a criação do vice-reinado do Prata. Que correspondia a uma necessidade espanhola. Portugal também não recebeu então o território dos Sete Povos das Missões. O aconteceu por conquista, mas só muitos anos depois (1801).$^{84}$ E poderá pensar-se que era essa uma necessidade na definição do espaço brasileiro.

Com o Tratado de Santo Ildefonso (1777) se conseguiu por fim a paz e, o que por então mais importava, manter para Portugal o domínio do Continente do Rio Grande - além da recuperação da Ilha de Santa Catarina. E da incorporação da imensidade da bacia do Amazonas e do interior Oeste, o Mato Grosso, que ficaram também em definitivo para os Portugueses. Sem que a dilatação empreendida por eles no Oeste tenha sido perdida ou sequer sofrido oposição. ${ }^{85}$ O território do Brasil ficava desenhado nas suas principais fronteiras - trabalho

${ }^{81}$ José Carlos de Macedo Soares, Fronteiras do Brasil no Regime Colonial, p. 171-189.

82 Ángel Sanz Tapia, El final del Tratado de Tordesillas: la expedición del virrey Cevallos al Río de la Plata, p. 37, 55 e 63.

${ }^{83}$ Guilhermino Cezar, História do Rio Grande do Sul. Época colonial, p. 180-182.

${ }^{84}$ Luís Ferrand de Almeida, Páginas dispersas. Estudos de História Moderna de Portugal, p. 176.

${ }^{85}$ Joaquim Romero Magalhães, “As novas fronteiras do Brasil”, in Francisco Bethencourt e Kirti Chauduri, direcção, História da Expansão Portuguesa, Lisboa, Círculo de Leitores, 1998, 
de diplomatas, mas trabalho de muitos dos homens que sulcaram o interior, que reconheceram e assinalaram caminhos possíveis e inventaram vias de comunicação. ${ }^{86}$ Eles fizeram o território do Brasil. Que os juristas e os políticos se esforçaram por confirmar e por ajustar. ${ }^{87}$ Triplicando as dimensões do território em relação ao que deveria ser o Brasil da delimitação de Tordesilhas. ${ }^{88}$ Mas que têm o seu sustentáculo no que as gerações de naturais, de portugueses, de africanos e depois de brasileiros natos foram fazendo. Para construir, definir e delimitar o território do imenso Brasil. E ainda garantir a sua posse.

Recebido: 17/09/12

Aceite: $14 / 04 / 12$

vol. 3, p. 13-35; Francisco Adolfo de Varnhagen, História Geral do Brasil, $5^{\mathrm{a}}$ ed., tomo Quatro, p. 201-202.

${ }^{86}$ Sérgio Buarque de Holanda, $O$ extremo Oeste, São Paulo, Brasiliense - Secretaria de Estado da Cultura, 1986, p. 89-92.

${ }^{87}$ Abeilard Barreto, “A opção portuguesa: restauração do Rio Grande e entrega da Colônia do Sacramento (1774-1777)", in História Naval Brasileira, Rio de Janeiro, Ministério da Marinha, 1979, p. 299-300.

${ }^{88}$ Basílio de Magalhães, Expansão geográfica do Brasil colonial, 4ª ed., São Paulo, Companhia Editora Nacional, 1978, p. 220-225. 